\title{
Preparation of fluorescent DNA probe by solid-phase organic synthesis
}

\author{
Z. Dai", P. Li, X. X. Sun, J. M. Zhang, S. C. Xu, N. Guo, X. Wang \\ Tianjin Key Laboratory of Fiber Modification and Functional Fiber, School of Environment and Chemical Engineering, \\ Tianjin Polytechnic University, 300160 Tianjin, China
}

Received 12 April 2009; accepted in revised form 20 May 2009

\begin{abstract}
Fluorescent DNA probe based on fluorescence resonance energy transfer (FRET) was prepared by solid-phase organic synthesis when CdTe quantum dots (QDs) were as energy donors and Au nanoparticles (AuNPs) were as energy accepters. The poly(divinylbenzene) core/poly(4-vinylpyridine) shell microspheres, as solid-phase carriers, were prepared by seeds distillation-precipitation polymerization with $2,2^{\prime}$-azobisisobutyronitrile (AIBN) as initiator in neat acetonitrile. The CdTe QDs and AuNPs were self-assembled on the surface of core/shell microspheres, and then the linkage of CdTe QDs with oligonucleotides (CdTe-DNA) and AuNPs with complementary single-stranded DNA (Au-DNA) was on the solid-phase carriers instead of in aqueous solution. The hybridization of complementary double stranded DNA (dsDNA) bonded to the QDs and AuNPs (CdTe-dsDNA-Au) determined the FRET distance of CdTe QDs and AuNPs. Compared with the fluorescence of CdTe-DNA, the fluorescence of CdTe-dsDNA-Au conjugates (DNA probes) decreased extremely, which indicated that the FRET occurred between CdTe QDs and AuNPs. The probe system would have a certain degree recovery of fluorescence when the complementary single stranded DNA was introduced into this system, which showed that the distance between CdTe QDs and AuNPs was increased.
\end{abstract}

Keywords: nanocomposites, fluorescent DNA probe, FRET, microspheres, solid-phase organic synthesis

\section{Introduction}

Fluorescent DNA probe is known as DNA biosensor based on fluorescence resonance energy transfer (FRET) which occurs when the electronic excitation energy of a donor chromophore is transferred to an acceptor molecule nearby via a through-space dipole-dipole interaction between the donor-acceptor pair [1]. The strong distancedependence of the FRET efficiency has been widely exploited in studying the structure and dynamics of proteins and nucleic acids, in the detection and visualization of intermolecular association and in the development of intermolecular binding assays [2].

As novel luminescent inorganic fluorophores, Quantum dots (QDs) are currently being widely used in biological probes, in vitro assay detection, in vivo cell labeling and imaging, because QDs show a broad and continuous excitation spectrum, narrow size-tunable symmetric emission spectrum and high fluorescence quantum yield [3-8]. Recently, complex nanostructures formed by linking QDs as energy donors and gold nanoparticles (AuNPs) as energy acceptors through DNA hybridization or streptavidin-biotin interaction have also been realized [9-13] and applied in the sensing biomolecular concentration [10]. AuNPs have a high extinction coefficient and a broad absorption spectrum in visible light that is overlapped by the emission wavelength of the usual energy donors. The key challenge of the hybrid DNA probe is to immobilize single-stranded DNA 
(ssDNA) onto the surfaces of QDs and AuNPs, respectively. The Gueroui and Libchaber [11] reported that carboxyl-modified QDs, activated with 1-ethyl-3-(3-dimethylaminopropyl) carbodiimide hydrochloride (EDC) and sulpho N-hydroxysuccinimide (NHS), could be covalently linked to ssDNA, streptavidin-coated QDs also could be conjugated with ssDNA [9]. ssDNA modified AuNPs were achieved by ssDNA being covalently linked to AuNPs functionalized with a single NHS ester $[11,14]$. In our previous works, we utilized the self-assembly of mercapto group modified ssDNA (HS-DNA) on AuNPs to simplify the process of probe preparation, and prepared DNA probe by the hybridization between QDs linked with a DNA sequence and AuNPs with a DNA strand [15]. However, because QDs and AuNPs both were less than $20 \mathrm{~nm}$ in diameters, it was hard to separate DNA probe from this mixture system. In reported works, the amount of nanoparticles (QDs or AuNPs) exceeded that of DNA $[11,15]$, thus less unreacted DNA would exist in system and the sep- aration and purification of ssDNA conjugated AuNPs (Au-DNA) and QDs (QD-DNA) from reaction system could be mainly focused on the utilization of the differences between free nanoparticles and ssDNA conjugated nanoparticles. In traditional way, nanoparticles which were not linked to DNA were not subject to purification processes $[12,15]$ or removed by ethanol precipitation [11] or spin filtration [13], and so on. Free ssDNA and nanoparticles which remained in system would influence the precision of detection and repetition ability of DNA probe. On the other hand, the structures of ssDNA conjugated AuNPS (Au-DNA) and QDs (QDDNA) and hybridized double-stranded DNA (dsDNA) probe were very complicated. Fu et al. [9] confirmed that a CdTe QD could be conjugated with 1 to 4 ssDNA, which resulted in the differences of the solubility and molecular weight of QD-DNA with different DNA number. Therefore, a more effective purification way with another mechanism should be investigated.

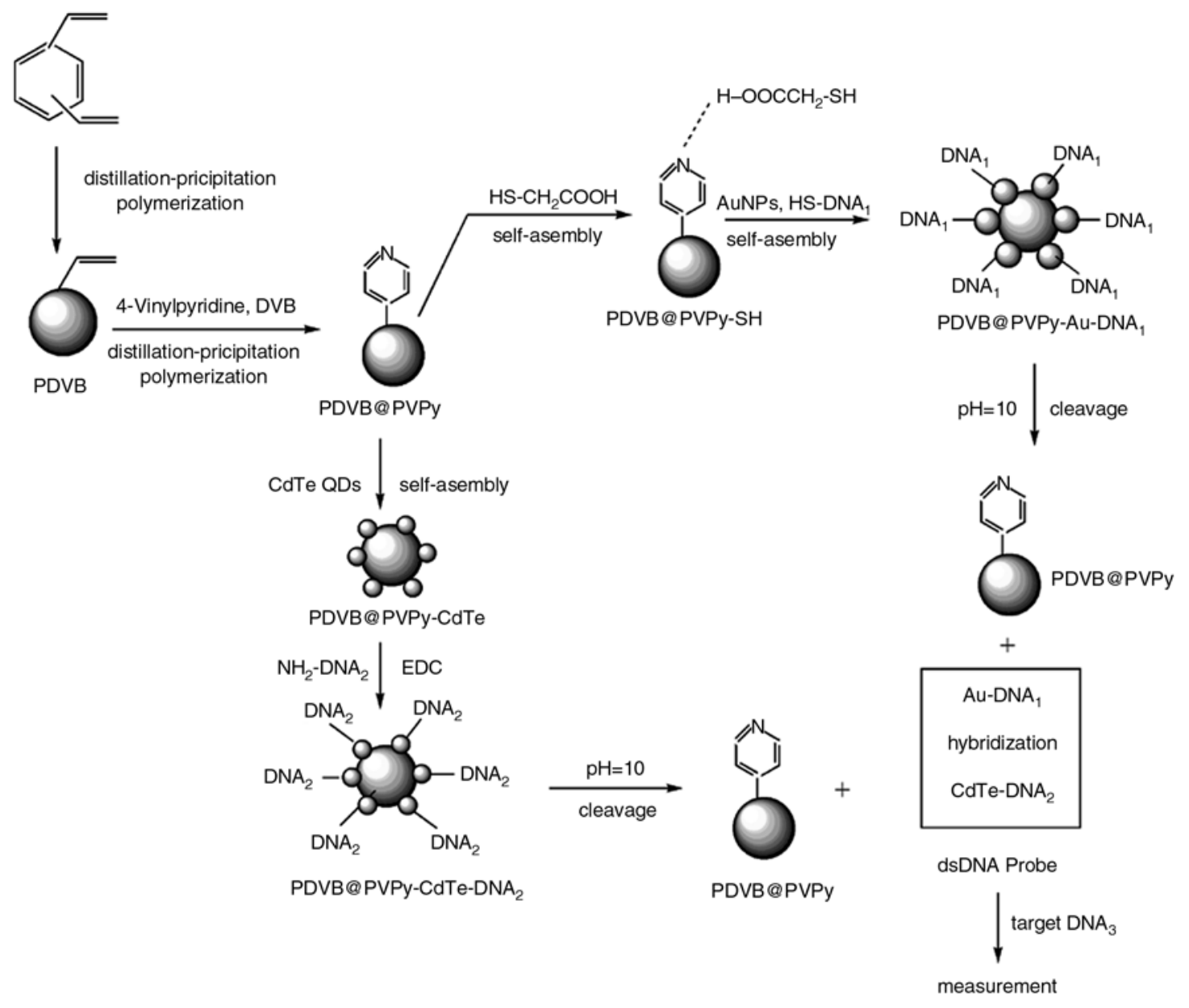

Figure 1. Illustration of preparation of fluorescent DNA probe on microspheres, and the base sequence of DNA $\mathrm{DNas}_{2}$ complementary with the base sequence of DNA 
The objective of the present work was to utilize functional polymeric micospheres as solid-phase carriers to simplify the process of probe purification. Because of the larger size of carriers, the free ssDNA and nanoparticles could be removed by filtration or centrifugation easily. The whole process was shown in Figure 1. Poly(divinylbenzene-80) (PDVB) microspheres as cores prepared by distillation-precipitation polymerization had a large average particle size $(>1 \mu \mathrm{m})$, which could be purified easily, and poly(4-vinylpyrindin) (PVPy) was coated on the PDVB core when PDVB microspheres were as seeds, 4-vinylpyrindin (VPy) as monomer and divinylbenzene-80 (DVB) as crosslinker by seeds distillation-precipitation polymerization. The ssDNA modified nanoparticles (Au-DNA and QD-DNA) were completed on the surface of PDVB/PVPy core/shell microspheres by self-assembly respectively. Only simple filtration or ultracentrifugation could remove the free ssDNA and nanoparticles because of the heterogeneous characteristic of solid-phase organic synthesis. The double-stranded DNA (dsDNA) probe was obtained when Au-DNA and CdTe-DNA were cleaved from the solid-phase carriers and hybridized each other.

\section{Experimental}

\subsection{Materials}

Divinylbenzene-80 (DVB, 80\% divinylbenzene isomers) was supplied by Aldrich Chemical Co. It was washed with $5 \%$ aqueous sodium hydroxide, water and then dried over anhydrous magnesium sulfate prior to use. 4-vinylpyrindin (VPy) was obtained from Aldrich Chemical Co. and purified by vacuum distillation before use. 2,2'-Azobisisobutyronitrile (AIBN) was analytical grade available from Tianjin Xida Rare Chemical Reagent Co. and was recrystallized from methanol. Acetonitrile (Tianjin Chemical Reagents II Co.) was dried over $4 \AA$ molecular sieves and distilled prior to utilization. All Other reagents were of analytical grade and used as received without any further purification. The fluorescent DNA probe was designed to hybridize to a 24 base portion of the Yersinia pestis (sequence 3). DNA oligonucleotides were purchased from Shanghai Invitrogen Biotechnique Co. Ltd., and the base sequences were listed as follows:
DNA Sequence 1: 5'-AGT AAG CAA GAG AGA GCC GGG GGG- $\left(\mathrm{CH}_{2}\right)_{6}-3^{\prime}-\mathrm{SH}$

DNA Sequence 2: $\mathrm{NH}_{2}-5^{\prime}-\left(\mathrm{CH}_{2}\right)_{6}$-GGC TCT CTC TTG CTT ACT- $3^{\prime}$

DNA Sequence 3: $5^{\prime}$-CCC CCC GGC TCT CTC TTG CTT ACT-3'

\subsection{Preparation of PVPy coated PDVB core/shell microspheres}

The core/shell microspheres (PDVB@PVPy) were prepared by seeds distillation-precipitation polymerization. In the first stage, poly(divinylbenzene) microspheres (PDVB) were prepared by distillation-precipitation polymerization when divinylbenzene-80 (DVB) (20 ml) as monomer and 2,2-azobisisobutyronitrile (AIBN) $(0.4 \mathrm{~g})$ as initiator in acetonitrile $(800 \mathrm{ml})$ [16], then the solid-phase carriers were obtained when PDVB microspheres were as seeds (0.5 g), 4-vinylpyridine (VPy) $(0.2 \mathrm{ml})$ as monomer, DVB $(0.4 \mathrm{ml})$ as crosslinker and AIBN $(0.02 \mathrm{~g})$ as initiator in acetonitrile $(80 \mathrm{ml})$ by seeds distillation-precipitation polymerization and the reaction was ended when $40 \mathrm{ml}$ of acetonitrile was distilled from the reaction system within $1.5 \mathrm{~h}$. The resultant polymer microspheres were separated and purified by vacuum filtration over a G5 sintered glass filter, and washed three times with tetrahydrofuran (THF), ethanol and acetone. The particles were dried at $40^{\circ} \mathrm{C}$ under vacuum overnight.

\subsection{Preparation of HS-DNA conjugated Au nanoparticles (Au-DNA)}

-SH modified microspheres (PDVB@ @PVPy-SH) were prepared by the self-assembly of thioglycollic acid (TGA, $700 \mu \mathrm{l})$ on the PDVB@PVPy microspheres $(0.4 \mathrm{~g})$ in ethanol-water solution $(30 \mathrm{ml}$, $5: 1 \mathrm{v} / \mathrm{v})$ at $37^{\circ} \mathrm{C}$ for $24 \mathrm{~h}$, the resultant PDVB@PVPy-SH microspheres were separated and purified by vacuum filtration over a G5 sintered glass filter and washed three times with ethanol-water solution $(5: 1 \mathrm{v} / \mathrm{v})$, and the particles were dried at $40^{\circ} \mathrm{C}$ under vacuum overnight. $\mathrm{Au}$ nanoparticles (AuNPs) prepared by the citrate reduction of $\mathrm{HAuCl}_{4}$ [17] with $16 \mathrm{~nm}$ in diameter, as energy acceptors, was purified by ultracentrifugation. Then AuNPs $(110 \mu \mathrm{l}, 0.2 \mathrm{mmol} / \mathrm{l})$ were 
self-assembled onto the surface of PDVB@PVPy$\mathrm{SH}$ microspheres $(0.02 \mathrm{~g})$ in ethanol-water solution $(20 \mathrm{ml}, 1: 1 \mathrm{v} / \mathrm{v})$ at $37^{\circ} \mathrm{C}$ for $24 \mathrm{~h}$ to get PDVB@PVPy-Au. Then, the residual pyridyl group on PDVB@PVPy-Au particles was protected by acetic acid $(100 \mu \mathrm{l})$ was added in solution at $37^{\circ} \mathrm{C}$ for $5 \mathrm{~h}$ under shake. The PDVB@PVPy-Au particles were purified by vacuum filtration and washed with ethanol-water solution $(1: 1 \mathrm{v} / \mathrm{v})$ for three times, and dried at $40^{\circ} \mathrm{C}$ under vacuum overnight. HS-DNA (Sequence 1, $33 \mu \mathrm{g}$ ) was mixed with purified PDVB@PVPy-Au microspheres in $10 \mathrm{ml}$ of water at $37^{\circ} \mathrm{C}$ for $16 \mathrm{~h}$. Then, the mixture solution was added into $10 \mathrm{ml}$ of phosphate buffer solution ( $\mathrm{PBS}, \mathrm{pH}=7.0$ ), and the HS-DNA were self-assembled on the solid-phase carriers (PDVB@PVPy-Au-DNA) at $37^{\circ} \mathrm{C}$ for $40 \mathrm{~h}$ under shake. The PDVB@PVPy-Au-DNA microspheres separated and purified by ultracentrifugation (7000 r/min for $30 \mathrm{~min}$ ) and washed with PBS $(\mathrm{pH}=7.0)$ for three times. Finally, the washed PDVB@PVPy-Au-DNA microspheres were resuspended in $5 \mathrm{ml}$ of water, and the Au-DNA was cut off from the carriers when $\mathrm{pH}$ was adjusted to 10.0 for $48 \mathrm{~h}$ at $50^{\circ} \mathrm{C}$ under shake. The carriers were removed by ultracentrifugation $(7000 \mathrm{r} / \mathrm{min}$ for $30 \mathrm{~min}$ ), and the $\mathrm{pH}$ of supernatant (Au-DNA aqueous solution) was adjusted to 7.0.

\subsection{Preparation of $\mathrm{NH}_{2}$-DNA conjugated CdTe QDs (QD-DNA)}

$3 \mathrm{~nm}$ of CdTe QDs in diameters as energy donors were prepared according to the reference work in aqueous solution when (3-mercaptopropionic acid) MPA was as stabilizer [15]. Before the self-assembly of QDs on microspheres, the $\mathrm{pH}$ of QDs aqueous solution was adjusted to 7.0 and purified by ethanol precipitation and ultracentrifugation (12 $000 \mathrm{r} / \mathrm{min}$ for $60 \mathrm{~min}$ ). After that, the CdTe QDs (17 $\mu \mathrm{l}, 0.25 \mathrm{mM}$ aqueous solution) were selfassembled on the PDVB@PVPy microspheres $(0.02 \mathrm{~g}$ in $20 \mathrm{ml}$ of ethanol-water solution $(1: 1 \mathrm{v} / \mathrm{v}))$ for $24 \mathrm{~h}$ at $37^{\circ} \mathrm{C}$ under shake because of the hydrogen-bonding between carboxyl of MPA on CdTe QDs and pyridine ring. Then, the residual pyridyl group on PDVB@PVPy-QDs particles was protected by acetic acid $(100 \mu \mathrm{l})$ was added in solution at $37^{\circ} \mathrm{C}$ for $5 \mathrm{~h}$ under shake. The PDVB@PVPyQDs microspheres were purified by ultracentrifu- gation (7000 r/min for $30 \mathrm{~min}$ ) and washed with ethanol-water solution $(1: 1 \mathrm{v} / \mathrm{v})$ for three times, and resuspended in $1 \mathrm{ml}$ Tris- $\mathrm{HCl}$ buffer $(10 \mathrm{mM}$ Tris$\mathrm{HCl}, 20 \mathrm{mM} \mathrm{NaCl}, \mathrm{pH}=7.2$ ). Then, $\mathrm{NH}_{2}$-DNA (sequence $2,33 \mu \mathrm{g}$ ) with $1 \mathrm{ml}$ Tris- $\mathrm{HCl}$ buffer (10 mM Tris- $\mathrm{HCl}, 20 \mathrm{mM} \mathrm{NaCl}, \mathrm{pH}=7.2)$ and 1-ethyl-3-(3-dimethylaminopropyl) carbodi-imide hydrochloride (EDC, $22 \mu \mathrm{l}, 0.01 \mathrm{M}, 50$-fold mole more than $\mathrm{NH}_{2}$-DNA) were added into the PDVB @ PVPy-QDs Tris-HCl buffer solution. The $\mathrm{NH}_{2}$-DNA was conjugated with QDs on the solid carriers (PDVB@PVPy-QD-DNA) at $37^{\circ} \mathrm{C}$ for $40 \mathrm{~h}$ under shake. Finally, the QD-DNA was cleaved from the carriers when $\mathrm{pH}$ was adjusted to 10.0 for $48 \mathrm{~h}$ at $50^{\circ} \mathrm{C}$ under shake. The carriers were removed by ultracentrifugation $(7000 \mathrm{r} / \mathrm{min}$ for $30 \mathrm{~min}$ ), and the $\mathrm{pH}$ of supernatant (QD-DNA aqueous solution) was adjusted to 7.0.

\subsection{Hybridization of QD-DNA and Au-DNA and detection of target DNA}

The resultant solution prepared in 2.3 and in 2.4 were mixed together and the hybridization of QDDNA and Au-DNA (the ratio of Au/QDs was about 10:1) was when a buffer solution of $20 \mathrm{mM}$ Tris$\mathrm{HCl}, 50 \mathrm{mM} \mathrm{KCl}$, and $5 \mathrm{mM} \mathrm{MgCl} 2(\mathrm{pH}=8.0)$ existed in system at $37^{\circ} \mathrm{C}$, for $1 \mathrm{~h}$ under shake. The detection program was as follows: target DNA (sequence $3,33 \mu \mathrm{g}$ ) was added into the $\mathrm{CdTe} /$ AuNPs conjugated probe system at $37^{\circ} \mathrm{C}$, for $1 \mathrm{~h}$ under shake, and the changes of fluorescent spectra of detection system were measured.

\subsection{Characterization}

The morphology of the resultant polymeric microspheres was determined by transmission electron microscopy (TEM) using a Tecnao G2 20 S-TWIN on a copper grid coated with a carbon membrane. Samples for TEM were dispersed in PBS buffer and a drop of the suspension was spread onto the surface of a thin carbon film supported on copper grid, then dried in vacuum.

The laser scanning confocal microscope (LSCM) images were obtained using Olympus FV1000S system. Samples of LSCM were dropped onto $35 \mathrm{~mm}$ glass-bottom culture dishes (Mattek Corp.) and were viewed by the LSCM microscope with $390 \mathrm{~nm}$ excitation and $570 \mathrm{~nm}$ emission. 
The fluorescence spectra of the probe system were measured with a WGY-10 Luminescence Spectrometer. According to Foster's theory, The FRET efficiency (quenching efficiency) could be measured experimentally and was commonly defined according to Equation (1) [18]:

$$
E=1-\frac{F_{D A}}{F_{D}}
$$

where $F_{D A}$ is the integrated fluorescence intensity of the donor in the presence of the acceptor(s) and $F_{D}$ is the integrated fluorescence intensity of the donor alone (no acceptors present).

The loading capacity of the pyridine group on the surface of polymer microspheres was measured by back-titration [19]: $0.3 \mathrm{~g}$ of PDVB@ @ PVPy microspheres were suspended in $25 \mathrm{ml}$ of $0.10 \mathrm{~mol} / \mathrm{l} \mathrm{HCl}$ solution with stirring for $5 \mathrm{~h}$ at room temperature. Then the resultant microspheres were separated by vacuum filtration over a G5 sintered glass filter and washed with distilled water for three times. The combined filtrate was re-titrated by $0.10 \mathrm{~mol} / \mathrm{l}$ $\mathrm{NaOH}$ aqueous solution with phenolphtalein as indicator. The loading capacity of the pyridyl group on the surface layer of the microspheres was calculated according to Equation (2):

$n_{p y}=\frac{c_{H C l} \cdot V_{H C l}-c_{\mathrm{NaOH}} \cdot V_{\mathrm{NaOH}}}{m}$

where $n_{p y}[\mathrm{mmol} / \mathrm{g}]$ is the accessible loading capacity of pyridyl group, $\mathrm{c}_{\mathrm{HCl}}$ is the concentration of $\mathrm{HCl}$ solution [mol/l], $\mathrm{V}_{\mathrm{HCl}}$ is the volume of $\mathrm{HCl}$ solution used for suspension [ml], $\mathrm{C}_{\mathrm{NaOH}}$ is the concentration of $\mathrm{NaOH}$ for titration [mol/l], $V_{\mathrm{NaOH}}$ is the volume of $\mathrm{NaOH}$ for titration [ml], $m$ is the weight of the microspheres determined $[\mathrm{g}]$, respectively.

\section{Results and discussion}

\subsection{PVPy coated PDVB core/shell microspheres}

Stöver et al. reported that highly crosslinked PDVB55 microspheres can be prepared with a diameter between 2 and $5 \mu \mathrm{m}$ by precipitation polymerization [20]. This reaction was carried out in bottles attached to a slowly rotating umbrellashaped rotor, and the residual double bonds located at the surface permit the further growth of the particles by radical capture of oligomers and monomers

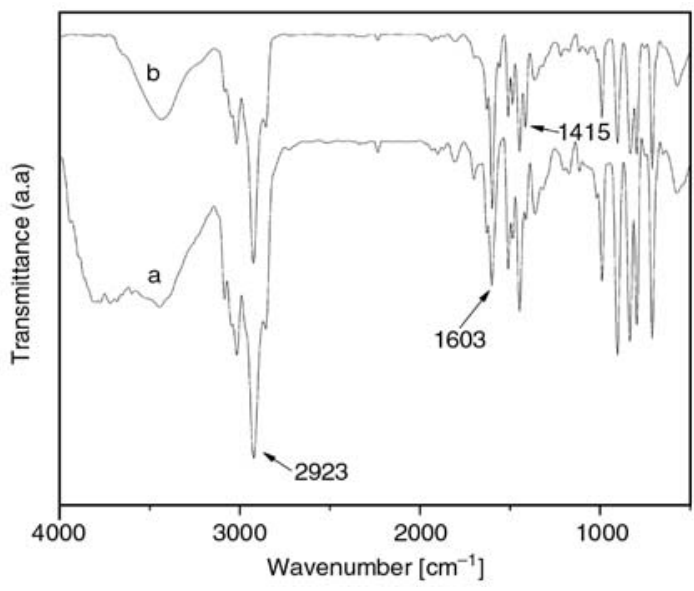

Figure 2. FT-IR spectra of polymer microspheres: a) PDVB microspheres; b) PDVB @P(VPy)

[21]. An important concern for core-shell polymerization is to retain the particle monodispersity. The distillation-precipitation polymerization was convenient to prepare PDVB80 microspheres in the absence of any stabilizer without stirring [16]. Moreover, Yang and coworkers found that monodispersity core/shell microspheres could be prepared by seeds distillation-precipitation polymerization easily with hydrophilic or hydrophobic monomer $[22,23]$. In this case, PDVB microspheres as cores prepared by distillation-precipitation polymerization had a large particle size $(>1 \mu \mathrm{m})$ which could be purified easily, and the residual double bonds on the surface of microspheres could be reacted with other vinyl monomer on the particle surfaces for future modification.

The FT-IR spectra of PDVB and poly(4-vinylpyridine) (PVPy) which had been coated PDVB core/shell microspheres (PDVB@PVPy) are shown in Figure 2. FT-IR spectra of PDVB microspheres (Figure $2 \mathrm{a}$ ) shows a peak at $2923 \mathrm{~cm}^{-1}$ attributed to the asymmetrical stretching of methylene groups while the band at $1603 \mathrm{~cm}^{-1}$ originated from the asymmetrical stretching of conjugated double bonds [21]. The increase of $1415 \mathrm{~cm}^{-1}$ absorptions was caused by the introduction of pyridine ring [24] (Figure 2b) of PDVB@ PVPy microspheres, and the loading capacity of the pyridyl group on the polymer microspheres was $0.134 \mathrm{mmol} / \mathrm{g}$.

\subsection{Preparation of DNA conjugated nanoparticles by solid-phase carriers}

CdTe QDs of about $3 \mathrm{~nm}$ diameter as energy donors were prepared in aqueous solution when 


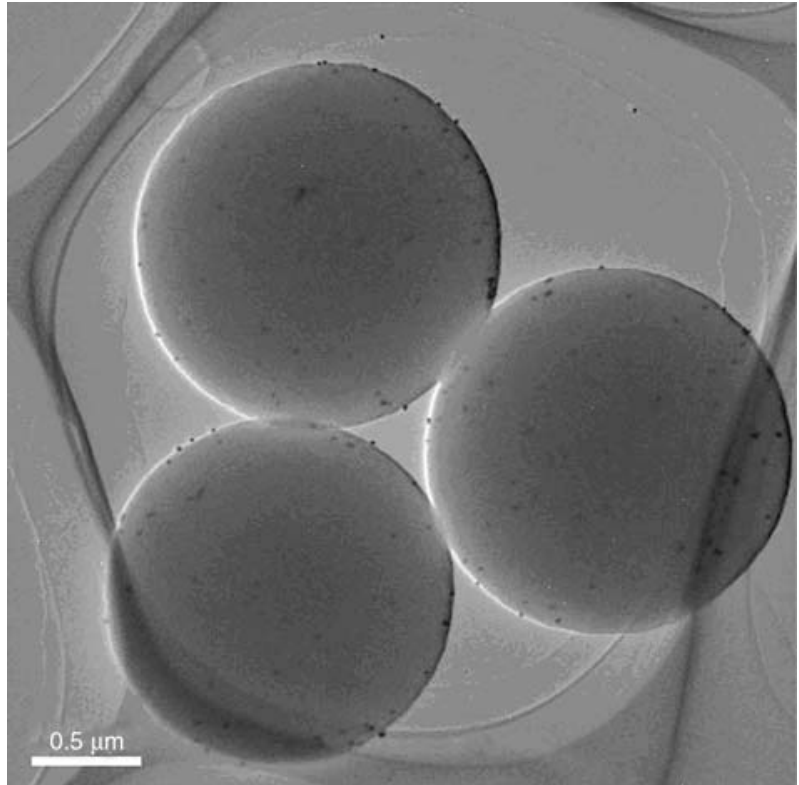

Figure 3. TEM graphs of Au-DNA on PDVB @ PVPy microspheres

(3-mercaptopropionic acid) MPA was used as stabilizer [15] and because of the large particle size and functional groups of core/shell microspheres, the synthesis of mercapto group modified ssDNA (HS-DNA, sequence 1) conjugated Au nanoparticles (Au-DNA) was completed on the surface of microspheres. The TEM graphs of Au-DNA on PDVB@PVPy microspheres (PDVB@PVPy-AuDNA) are shown in Figure 3.

AuNPs were prepared by the citrate reduction of $\mathrm{HAuCl}_{4}$ [17] with $16 \mathrm{~nm}$ in diameter. The results indicated that the particle size of PDVB@PVPy microspheres was about $1.65 \mu \mathrm{m}$ and the Au-DNA conjugates were self-assembled on the surface of microspheres successfully. The large size of carriers made it easily for PDVB@PVPy-Au-DNA microspheres to be separated and purified from the reaction system. Li et al. [19] prepared poly(ethyleneglycol dimethacrylate-co-4-vinylpyridine) (P(EGDMA-co-VPy)) microspheres by distillationprecipitation copolymerization, and only when the fraction of VPy was higher that $40 \%(\mathrm{v} / \mathrm{v})$ in total monomer, the particle size of P(EGDMA-co-VPy) could be over $1 \mu \mathrm{m}(1.72 \mu \mathrm{m})$ and the loading capacity of pyridyl group on microspheres was about $1.76 \mathrm{mmol} / \mathrm{g}$. However, in this work, the loading capacity of pyridyl group on carriers should be controlled at a very low level because the amount of AuNPs and ssDNA were both trace amounts to avoid the interaction between excessive

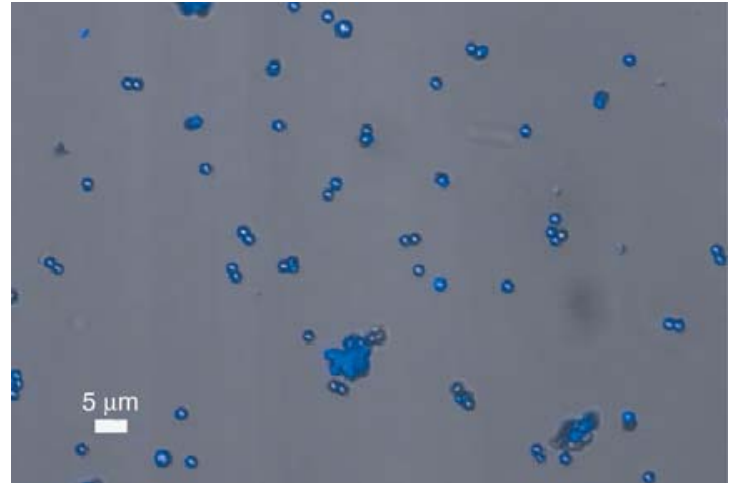

Figure 4. LSCM graphs of PDVB @ PVPy-QD-DNA

pyridyl group on carriers and HS-DNA. Therefore, the structure of suitable carriers was PDVB/PVPy core/shell microspheres, when PDVB core provided a large size in diameters and PVPy shell had a low loading capacity of pyridyl group (about $0.134 \mathrm{mmol} / \mathrm{g}$ ).

The laser scanning confocal microscope (LSCM) graphs of $\mathrm{NH}_{2}$-DNA (sequence 2, complementary with sequence 1) conjugated CdTe QDs (QD-DNA) on PDVB@PVPy microspheres (PDVB@PVPyQD-DNA) are shown in Figure 4, which indicated that the ssDNA conjugated QDs (QD-DNA) were self-assembled on the surface of microspheres.

In traditional way, the amount of nanoparticles (QDs or AuNPs) is in excess of DNA [11,15] to reduce the influence of residual unreacted ssDNA, but which resulted in the residue of nanoparticles, especially when the particle size was too small, for example QDs was only about $2-3 \mathrm{~nm}$ in size [15]. The residual free QDs would increase the background fluorescence of probe based on inorganic nanoparticles, and the residual unreacted ssDNA would hybridize with the complementary ssDNA in the system.

In this work, the amount of QDs and ssDNA were nearly equal, and only simple filtration could remove the free ssDNA and nanoparticles because of the huge difference of particle sizes between solid-phase carriers and ssDNA rather than the slight difference of particle size or solubility between residual free nanoparticles and ssDNA conjugated nanoparticles in traditional ways $[11-13,15]$. When the $\mathrm{pH}$ was about 10 , the AuDNA and QD-DNA were cut off from the carriers. After hybridization of Au-DNA and QD-DNA in a buffer solution $(\mathrm{pH}=8)$, the double-stranded (dsDNA) fluorescent DNA probe was obtained. 


\subsection{Detection of DNA probe}

According to the FRET process, when the distance between the donor and acceptor was $1-10 \mathrm{~nm}$ and the emission spectrum of the donors could overlap the absorption spectrum of the acceptors, the energy could be transferred from the energy donors to acceptors $[1,25]$. CdTe QDs and AuNPs are a suitable donor-acceptor pair [13] because the emission spectrum of CdTe QDs and the absorption spectrum of AuNPs have a large overlap [15]. After hybridization between CdTe-DNA and Au-DNA, the CdTe and Au nanoparticles were close, therefore the fluorescence intensity of donors would decrease because of the energy transfer from the donors to acceptors and the formation of fluorescence probes with inorganic nanoparticles conjugated double-stranded DNA (QD-dsDNA-Au probe) $[14,15]$. The fluorescence emission spectra of the QD-DNA, QD-dsDNA-Au probe, and QDdsDNA-Au probe with single-stranded target DNA (sequence 3, completely complementary with sequence 1) are shown in Figure 5.

Compared with the fluorescence intensity of QDDNA, the fluorescence intensity of QD-dsDNA-Au probe decreased tremendously, which indicated that the FRET process occurred in the QD-dsDNAAu conjugated system after the hybridization program, and the quenching efficiency was about $73.7 \%$. In our previous work, the quenching efficiency was $55-67 \%$ obtained when the QDs reacted with ssDNA with no purification [15]. In most cases, the background fluorescence of DNA

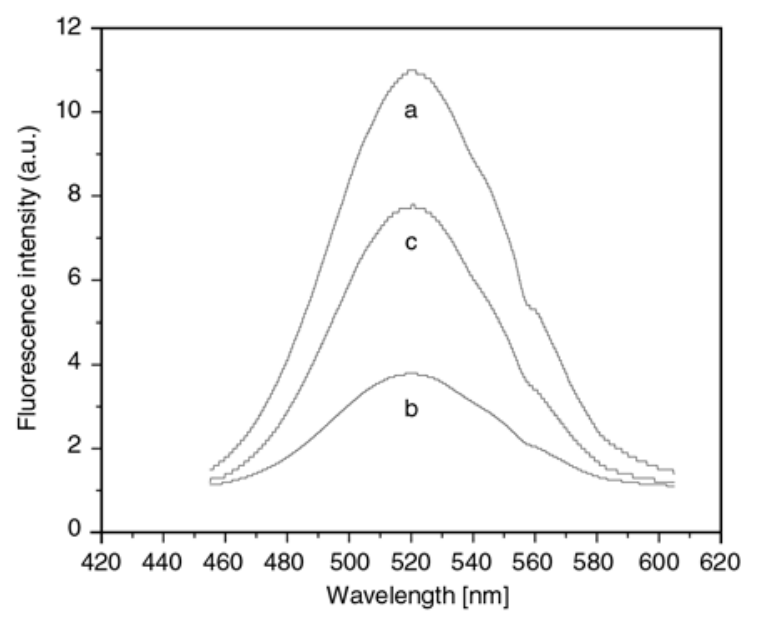

Figure 5. Fluorescence spectra of QD-DNA (a), QD-dsDNA-Au probe (b) and QD-dsDNA-Au probe with target DNA (c) probes with inorganic nanoparticles conjugated double-stranded DNA (QD-dsDNA-Au probe) was a common phenomenon [15, 26-27], because of the residual QDs and ratio of energy acceptors/donors, which resulted in a limit of FRET efficiency (quenching efficiency). Zhang et al. increased the number of energy acceptors (Cy5) which surrounded energy donors (QDs) to get a low level of background fluorescence [28]. AuNPs-DNA could be separated from reaction system by ultracentrifugation because of its larger particle size $(>10 \mathrm{~nm})$. However, the particle size of QDs was too small (2-3 nm) which caused the residue of unreacted QDs and ssDNA in the QD-DNA solution. The free QDs increased the background fluorescence, and when these free ssDNA (sequence 2) hybridized with ssDNA (sequence 1) on AuNPs, no FRET process could occur in that structure, which would decrease the quenching efficiency. Therefore when there was no purification process in preparation of QD-DNA, the quenching efficiency was lower (55-67\%) by changing the ratio of acceptors/ donors (Au-DNA/QD-DNA), and quenching efficiency reached the maximum (about 67\%) when the Au-DNA/QD-DNA was 10:1 [15]. In this work, the separation and purification were easier because of the large size of solid carriers (about $1.6 \mu \mathrm{m}$ in diameters), and the quenching efficiency was increased to $73.7 \%$ when the Au-DNA/QDDNA was 10:1. But the background fluorescence phenomenon still existed, which indicated that the future work would be focused on the control of ratio of AuNPs/QDs.

After target single-stranded DNA (sequence 3, complementary with sequence 1) was introduced into the probe system, the double-stranded DNA of the probe system opened and the distance between the CdTe QDs and Au nanoparticles increased. The target DNA could replace the DNA (sequence 2) on the QDs surface and hybridize with the DNA (sequence 1) on $\mathrm{Au}$ nanoparticles, because the target DNA had more complementary bases than the sequence 2 DNA, which resulted in a stronger hydrogen-bonding between the target DNA and the sequence 1 DNA, thus the fluorescent intensity of the system was recovered about 2.4 times than that of probe. 


\section{Conclusions}

Fluorescent DNA probe which can be used as DNA biosensor was prepared by solid-phase organic synthesis on polymer functional core/shell microspheres in large diameters. PDVB microspheres as cores provided the large particles size in diameters and PVPy shell was coated on the PDVB cores were obtained by seeds distillation-precipitation polymerization. The preparation of Au-DNA and QD-DNA were on the PVPy functional shell respectively. After the hybridization program, the FRET occurred because the donors and acceptors were close enough and the quenching efficiency was about $73.7 \%$. When complete complementary target DNA was added into this probe system, the fluorescence intensity of this system was recovered about 2.4 times than that of probe.

\section{Acknowledgements}

This work was supported by the National Natural Science Foundation of China (No. 20802051), Science and Technology Development Foundation of Tianjin Universities (No. 20070608) and Natural Science Foundation of Tianjin (No. 07JCYBJC15900).

\section{References}

[1] Wu P., Brand L.: Resonance energy transfer: Methods and applications. Analytical biochemistry, 218, 1-13 (1994). DOI: $\underline{10.1006 / a b i o .1994 .1134}$

[2] Willard D. M., Carillo L. L., Jung J., Orden A. V.: $\mathrm{CdSe}-\mathrm{ZnS}$ quantum dots as resonance energy transfer donors in a model protein-protein binding assay. Nano Letters, 1, 469-474 (2001). DOI: $\underline{10.1021 / \mathrm{nl} 015565 \mathrm{n}}$

[3] Dahan M., Laurence T., Pinaud F., Chemla D. S., Alivisatos A. P., Sauer M., Weiss S.: Time-gated biological imaging by use of colloidal quantum dots. Optics Letters, 26, 825-827 (2001). DOI: $10.1364 /$ OL.26.000825

[4] Alivisatos A. P.: Semiconductor clusters, nanocrystals, and quantum dots. Science, 271, 933-937 (1996). DOI: $\underline{10.1126 / \text { science. } 271.5251 .933}$

[5] Chan W. C. W., Nie S.: Quantum dot bioconjugates for ultrasensitive nonisotopic detection. Science, 281, 2016-2018 (1998). DOI: $10.1126 /$ science.281.5385.2016

[6] Jaiswal J. K., Mattoussi H., Mauro J. M., Simon S. M.: Long-term multiple color imaging of live cells using quantum dot bioconjugates. Nature Biotechnology, 21, 47-51 (2003). DOI: $\underline{10.1038 / \mathrm{nbt} 767}$
[7] Wu X., Liu H., Liu J., Haley K. N., Treadway J. A., Larson J. P., Ge N., Peale F., Bruchez M. P.: Immunofluorescent labeling of cancer marker Her2 and other cellular targets with semiconductor quantum dots. Nature Biotechnology, 21, 41-46 (2003).

DOI: $10.1038 / n b t 764$

[8] Sapsford K. E., Pons T., Medintz I. L., Mattoussi H.: Biosensing with luminescent semiconductor quantum dots. Sensors, 6, 925-953 (2006).

DOI: $10.3390 / \mathrm{s} 6080925$

[9] Fu A. H., Micheel C. M., Cha J., Chang H., Yang H., Alivisatos A. P.: Discrete nanostructures of quantum dots/Au with DNA. Journal of the American Chemical Society, 126, 10832-10833 (2004).

DOI: $\underline{10.1021 / \mathrm{ja} 046747 \mathrm{x}}$

[10] Oh E., M. Hong M-Y., Lee D., Nam S-H., Yoon H. C., Kim H-S.: Inhibition assay of biomolecules based on fluorescence resonance energy transfer (FRET) between quantum dots and gold nanoparticles. Journal of the American Chemical Society, 127, 3270-3271 (2005). DOI: 10.1021/ja0433323

[11] Gueroui Z., Libchaber A.: Single-molecule measurements of gold-quenched quantum dots. Physical Review Letters, 93, 166108/1-166108/4 (2004). DOI: 10.1103/PhysRevLett.93.166108

[12] Kim J. H., Morikis D., Ozkan M.: Adaptation of inorganic quantum dots for stable molecular beacons. Sensors and Actuators B: Chemical, 102, 315-319 (2004). DOI: $\underline{10.1016 / j . s n b .2004 .04 .107}$

[13] Cady N. C., Strickland A. D., Batt C. A.: Optimized linkage and quenching strategies for quantum dot molecular beacons. Molecular and Cellular Probes, 21, 116-124 (2007). DOI: $10.1016 /$ j.mcp.2006.09.001

[14] Dyadyusha L., Yin H., Jaiswal S., Brown T., Baumberg J. J., Booy F. P., Melvin T.: Quenching of CdSe quantum dot emission, a new approach for biosensing. Chemical Communications, 25, 3201-3203 (2005). DOI: $10.1039 / \mathrm{b} 500664 \mathrm{c}$

[15] Dai Z., Zhang J. M., Dong Q. X., Guo N., Xu S. C., Sun B., Bu Y. H.: Adaption of Au nanoparticles and CdTe quantum dots in DNA detection. Chinese Journal of Chemical Engineering, 15, 791-794 (2007). DOI: $\underline{10.1016 / S 1004-9541(08) 60004-X}$

[16] Bai F., Yang X. L., Huang W. Q.: Synthesis of narrow or monodisperse poly(divinylbenzene) microspheres by distillation-precipitation polymerization. Macromolecules, 37, 9746-9752 (2004). DOI: $10.1021 / \mathrm{ma} 0485661$

[17] Fren G.: Preparation of gold dispersions of varying particle size: Controlled nucleation for the regulation of the particle size in monodisperse gold suspensions. Nature: Physical Science, 241, 20-22 (1973). 
[18] Pons T., Medintz I. L., Sapsford K. E., Higashiya S., Grimes A. F., English D. S., Mattoussi H.: On the quenching of semiconductor quantum dot photoluminescence by proximal gold nanoparticles. Nano Letters, 7, 3157-3164 (2007).

DOI: $10.1021 / \mathrm{nl} 071729+$

[19] Li S-N., Yang X-L., Huang W-Q.: Preparation of polymer microspheres with pyridyl group and their stabilized gold metallic colloids. Chinese Journal of Polymer Science, 25, 555-563 (2007). DOI: $\underline{10.1142 / \mathrm{S} 0256767907002461}$

[20] Li W-H., Stöver H. D. H.: Porous monodisperse poly(divinylbenzene) microspheres by precipitation polymerization. Journal of Polymer Science Part A: Polymer Chemistry, 36, 1543-1551 (1998).

DOI: $10.1002 /($ SICI $) 1099-0518(19980730) 36: 10$ $\leq 1543::$ AID-POLA7>3.0.CO;2-R

[21] Downey J. S., Frank R. S., Li W-H., Stöver H. D. H.: Growth mechanism of poly (divinylbenzene) microspheres in precipitation polymerization. Macromolecules, 32, 2838-2844 (1999). DOI: $10.1021 / \mathrm{ma9812027}$

[22] Bai F., Yang X., Zhao Y., Huang W.: Synthesis of core-shell microspheres with active hydroxyl groups by two-stage precipitation polymerization. Polymer International, 54, 168-174 (2005). DOI: $10.1002 /$ pi.1670

[23] Qi D., Bai F., Yang X., Huang W.: Synthesis of coreshell polymer microspheres by two-stage distillationprecipitation polymerization. European Polymer Journal, 41, 2320-2328 (2005). DOI: $10.1016 /$ j.eurpolymj.2005.04.034
[24] Luyten M. C., Alberda van Ekenstein G. O. R., Wildeman J., ten Brinke G., Ruokolainen J., Ikkala O., Torkkeli M., Serimaa R.: Ordering in supramolecular elastomer-amphiphile systems. 4. Vinylpyridinedivinylbenzene networks with alkylphenols. Macromolecules, 31, 9160-9165 (1998).

DOI: $\underline{10.1021 / \mathrm{ma} 9808833}$

[25] Clapp A. R., Medintz I. L., Mauro J. M., Fisher B. R., Bawendi M. G., Mattoussi H.: Fluorescence resonance energy transfer between quantum dot donors and dyelabeled protein acceptors. Journal of the American Chemical Society, 126, 301-310 (2004). DOI: $10.1021 / \mathrm{ja0} 037088 \mathrm{~b}$

[26] Wang T-H., Peng Y-H., Zhang C., Wong P. K., Ho CM.: Single-molecule tracing on a fluidic microchip for quantitative detection of low-abundance nucleic acids. Journal of the American Chemical Society, 127, 5354-5359 (2005).

DOI: $10.1021 / \mathrm{ja042642 \textrm {i }}$

[27] Zhang C. Y., Chao S. Y., Wang T. H.: Comparative quantification of nucleic acids using single-molecule detection and molecular beacons. Analyst, 130, 483-488 (2005).

DOI: $10.1039 / \mathrm{b} 415758 \mathrm{c}$

[28] Zhang C-Y., Yeh H-C., Kuroki M-T., Wang T-H.: Single-quantum-dot-based DNA nanosensor. Nature Materials, 4, 826-831 (2005).

DOI: $\underline{10.1038 / \mathrm{nmat} 1508}$ 